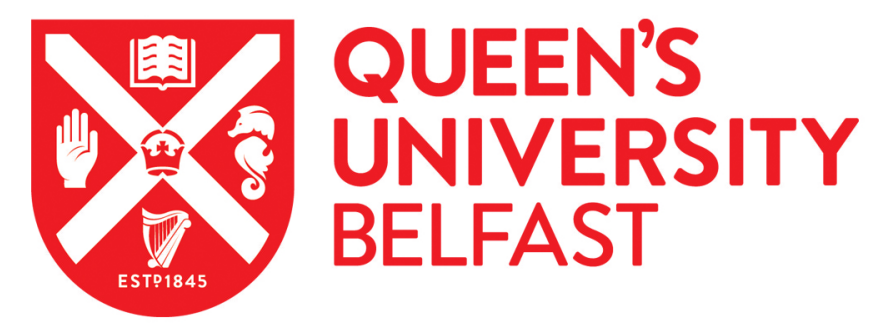

\title{
Shifting the Paradigm on Cultural Property and Heritage in International Law and Armed Conflict: Time to Talk about Reparations?
}

Moffett, L., Viejo Rose, D., \& Hickey, R. (2019). Shifting the Paradigm on Cultural Property and Heritage in International Law and Armed Conflict: Time to Talk about Reparations? time to talk about reparations? International Journal of Heritage Studies. https://doi.org/10.1080/13527258.2019.1666295, https://doi.org/10.1080/13527258.2019.1666295

\section{Published in:}

International Journal of Heritage Studies

\section{Document Version:}

Peer reviewed version

Queen's University Belfast - Research Portal:

Link to publication record in Queen's University Belfast Research Portal

\footnotetext{
Publisher rights

Copyright 2019 Oxford University Press. This work is made available online in accordance with the publisher's policies. Please refer to any applicable terms of use of the publisher.
}

\section{General rights}

Copyright for the publications made accessible via the Queen's University Belfast Research Portal is retained by the author(s) and / or other copyright owners and it is a condition of accessing these publications that users recognise and abide by the legal requirements associated with these rights.

Take down policy

The Research Portal is Queen's institutional repository that provides access to Queen's research output. Every effort has been made to ensure that content in the Research Portal does not infringe any person's rights, or applicable UK laws. If you discover content in the Research Portal that you believe breaches copyright or violates any law, please contact openaccess@qub.ac.uk. 


\section{Shifting the Paradigm on Cultural Property and Heritage in International Law and Armed Conflict: Time to Talk about Reparations?}

The demolition of the mausoleums in Timbuktu, the destruction of the Temple of Bel in Palmyra, and the aerial bombardment of the Old City of Sana'a in Yemen - each mark a continuing trend of intentionally targeting cultural property, and disregard for its protection under international humanitarian law. From as far back as records of war exist, through to contemporary conflicts, cultural sites have been targeted by states and non-state armed groups. This destruction is used as a means to delegitimise opponents and displace their populations, reject the symbols of a regime, disrupt a sense of continuity for communities and corrode collective identities (Brosché et al. 2017; \& Ascherson 2005). While international law has focused on a three-P approach (hereafter 'PPP'), imposing obligations on states to preserve, protect and prosecute the destruction of cultural property, treaties in this area remain silent on the aftermath of such violence with little attention to reconstruction or reparative measures, thus further endangering sites. Moreover, such treaties emphasise the physical and proprietary manifestations of heritage, neglecting its more intangible manifestations that are equally destroyed - such as language, traditions, oral history, songs and dance (Blake 2017). As a result there is a vast lacuna in addressing the real impact of war on communities whose cultural heritage, and through it the cultural bonds between individuals and across generations, is destroyed.

Notwithstanding the high stakes, reparations for the destruction of cultural property were neglected as an approach in international law and practice, since destroying or looting cultural property were often treated as legitimate reprisals ${ }^{1}$ or spoils of war. ${ }^{2}$ There is some emerging literature that uncovers the serious harm caused by the destruction of cultural heritage (Novic 2016), and heritage studies explores the significance of cultural heritage for communities and the challenges of reconstructing it in the aftermath of conflict (Viejo Rose 2013). However, there has been little analysis of the legal regime for reparations for the destruction of cultural heritage. There is growing attention to reparations for indigenous people and their culture (Lenzerini 2008; Article 11(2), United Nations 2007); but not in terms of conflict related destruction and post-conflict transitions (Vrdoljak 2008; 2011). Most 
of the literature on cultural property focuses on its destruction in armed conflict and the current PPP legal regime (Cunliffe et al 2016; O’Keefe 2006; Woodhead 2014), reflecting a property law focus in response to the mass looting of art and other cultural property during the Second World War, and neglecting the destruction of immoveable and intangible cultural heritage and its impact on communities, groups and peoples. There is increasing recognition of cultural property and heritage being protected not only for their historic/cultural value, but also because of what they represent to the identity and culture of particular groups of people (Abtahi 2001).

Leaving aside issues of looting of moveable cultural property and restitution efforts since the World Wars, this article traces emerging customary practice on the award of reparations for the destruction of cultural property. We begin by outlining the preserve, protect, and prosecution regime in international law, before introducing the role of reparations for cultural property and heritage. We follow this by discussing the harm caused by destruction of cultural property and heritage. We are especially interested in approaches that go beyond restitution and try to engage with the harm caused to groups and communities affected by cultural loss. In particular we argue that the PPP approach should be adjusted to reflect the emerging practice of reparations, drawing from the growing scope of heritage studies, transitional justice practice and international jurisprudence. We argue that talking about reparations refocuses attention beyond tangible property, and only then can we address the harm suffered by victims and communities when their cultural heritage is deliberately targeted. The main part of our article traces out the contours of what appropriate reparations for the destruction of cultural property and heritage can look like, paying particular attention to determinations of eligible victims, appropriate forms, responsibility and the practical challenges of reparations. We conclude by reflecting on moving forward with the PPPR approach, whereby reparations are included in future resolutions, treaties and policies on cultural property and heritage, not only as a means of international cooperation, but to allow for bottom up approaches and recognition of the role of affected individuals, groups, communities and peoples in such restoration. 


\section{The Emerging Recognition of Reparations for the Destruction of Cultural}

\section{Heritage in International Law}

Since the nineteenth century, international humanitarian law has provided rules against damaging or occupying cultural property during armed conflict, and has punished those who intentionally or through negligence damage or destroy such property (O'Keefe 2006, 13-34). Despite these proscriptions, international law adopts a rather fatalistic view on reparations, as was apparent in the Jokić case concerning the shelling of Dubrovnik:

'Restoration of buildings of this kind, when possible, can never return the buildings to their state prior to the attack because a certain amount of original, historically authentic, material will have been destroyed, thus affecting the inherent value of the buildings. ${ }^{3}$

Such a view of reparations assumes that the authenticity of cultural heritage is entirely dependent on its materiality. It also presents heritage as fixed in a historic moment and unchanging, when it might better be understood as the outcome of a continuous process of interpretation and meaning-making. (Kirshenblatt-Gimblett 1995; Harvey 2001) As a consequence, attention has been placed on prosecution and punishment in the hope of deterring future perpetrators, but this leaves little remedy for the victims of such crimes or satisfactory measures of repair.

The destruction of cultural property was first internationally penalised under Article 56 of the 1899 Hague Convention, ${ }^{4}$ which stipulated reparations through compensation to injured parties to be paid by the responsible state for its violations. ${ }^{5}$

During the drafting of the Genocide Convention delegates also proposed that appropriate redress should look to the 'reconstitution of the moral, artistic and cultural inheritance of the group (reconstruction of monuments, libraries, universities, churches, etcetera., and compensation to the group for its collective needs)' ${ }^{6}$ But again the punitive approach prevailed in the final draft of the Genocide Convention, which dropped all reference to remedy or reparation, focusing on prosecution and punishment, rather than cultural destruction and reparations.

This protect, preserve and prosecute (PPP) approach is evident in the 1954 Hague Convention on the Protection of Cultural Property in the Event of Armed Conflict. ${ }^{7}$ In terms of reparations the drafters of the Convention found that 'the possibility of civil reparations is of very minor interest when we are concerned with property which is essentially irreplaceable' (UNESCO 1950, 2). Reparations are 
mentioned in the First Protocol of the 1954 Convention, which explicitly prohibits the expropriation of cultural property by invading armed forces in response to a country breaching its international obligations. ${ }^{8}$ This may suggest that cultural property cannot be retained as the spoils of war and that there is an obligation to return such property after a conflict (Lijnzaad 2010, 154). The 1999 Second Protocol to the Hague Convention for the Protection of Cultural Property, under Article 38 stipulates that the Convention does not affect state responsibility, in particular reparations. State responsibility for breaches of international obligations was set down in the Chorzow Factory case (1927):

'It is a principle of international law that the breach of an engagement involves an obligation to make reparation in an adequate form. Reparation therefore is the indispensable complement of a failure to apply a convention and there is no necessity for this to be stated in the convention itself.' 9

Accordingly the lack of reference to reparations in the 1954 Hague Convention does not mean that reparations cannot derive from a state's failure to fulfil its obligations therein.

The absence of a concerted reparation approach to the damage and destruction of cultural property in international law has led to the development of soft law approaches through resolutions of international organisations and professional bodies with mandates for the protection of cultural heritage. For the most part these organisations have concentrated on the protection of cultural heritage and preventive measures with regards to its intentional destruction. ICCROM, for instance, has been running training in 'First Aid to Cultural Heritage in Times of Crisis' for a number of years, and there have been comparable initiatives from UNESCO, the Council of Europe and ICOMOS (for instance UNESCO 2015; 2018). The destruction of the Old Town of Warsaw in particular inspired a change in attitudes towards what constitutes authenticity when a heritage site is so completely destroyed that it has to be reconstructed with very limited original material. In order to inscribe the rebuilt Old Town of Warsaw as World Heritage, the understanding of authenticity and legitimate restoration inscribed in the Venice Charter (1964) had to be reconsidered. Yet, despite the important amount of work on post-war reconstruction and recovery of cultural heritage that often includes careful assessment of its potential for reconciliation ${ }^{10}$ until recently the remedial approach has largely focused on the restitution of cultural 
property unlawfully removed during armed conflicts (UNESCO 1970; UNIDROIT 1995). Where the work of these organisations has most approached remedial approaches is in relation to reparations to the cultural destruction and harm suffered by indigenous communities (Vrdoljak 2008).

This paucity of reparations for destruction of cultural property is anomalous given the increasing importance such measures are given in remedying states' breaches of international law. Reparations in international law are meant to restore the injured party to status quo ante (original position) through restitutio in integrum (return to the victim all they have lost) (Shelton 2005, 9 and 25). ${ }^{11}$ The Permanent Court of International Justice stated in the Chorzow Factory case that reparations are intended to 'as far as possible, wipe-out all the consequences of the illegal act and reestablish the situation which would, in all probability, have existed if that act had not been committed'. ${ }^{12}$ This approach was to a large extent applied in the reconstruction of Mostar Bridge, where the rebuilding was carried out with great care to use the original materials and replicate the destroyed structure, but not under the rubric of state responsibility for wrongful acts, but as a means of reconciliation (Viejo Rose 2013, 128). The aspiration of reconstructing a heritage site as if the act of violence that destroyed it had not been committed however, has been criticised as counterproductive to the aims of socio-cultural recovery (Viejo Rose 2013, 135). Arguably it prosecution at the ICTY also signifies greater attention to individual criminal responsibility rather than state responsibility for the destruction of cultural property (Vrdoljak 2011, 18).

International human rights law has given more depth to redress, looking beyond inter-state claims to allow individuals and communities to seek redress against the state. Human rights courts have also recognised the individual and collective, moral and pecuniary, physical and psychological dimensions of harm caused to attacks on cultural heritage. This more holistic approach uses a number of complementary remedies that seek to adequately and appropriately acknowledge and alleviate the suffering of the victim(s). In particular human rights has recognised the cultural value of heritage when it comes to indigenous or tribal peoples, though there have been a few cases involving destruction of cultural property during conflict. This case law, discussed further below, has taken on board the suffering of communities affected by the destruction of cultural heritage and tries to provide appropriate forms of reparations. 


\section{The harm caused by the destruction of cultural heritage}

Cultural heritage can suffer various types of harm during armed conflict. The harm begins as virulent propaganda, which sets the scene for violence propagating exclusionary narratives, setting new norms, and redrawing the lines of belonging. Cultural heritage is particularly vulnerable to attack during this early phase either as representing a past to be discarded - consider revolutionary moments such as the Chinese Cultural Revolution (1966) during which the Four Olds were targeted: Old Customs, Old Culture, Old Habits, and Old Ideas - or as a manifestation of difference that is no longer tolerated, such as Cham mosques in Khmer Rouge ruled Cambodia (Killean et al 2018). As armed conflict looms the depletion of human resources further makes cultural heritage vulnerable as government structures weaken, professional activities are disrupted, rule of law collapses, and personnel are denied access to the heritage sites and collections under their care. Heritage sites are also deliberately targeted for the menacing messages such actions send to local, national and international onlookers, for example. the Taliban's destruction of the Buddha statues of Bamiyan (Singh, 2014).

Violence against heritage can target all of its manifestations including structures and monuments, spaces and landscapes, movable items and artefacts, as well as traditions and ways of life. Depending on the motivations and aims of the destruction, physical harm to structures can take many forms, from the obliteration of a site to more symbolic gestures of decapitating statues depicting political, religious or cultural leaders. The physical destruction of a site can also be carried out in a way that targets the intangible heritage of communities - for instance mosques being used as pig corals by the Khmer Rouge - causing moral harm and damaging social cohesion by erasing communal meeting spaces. The forced displacement of people further transforms cultural spaces as traditional habitations are abandoned by one group, occupied by another, communities are dispersed or herded together in camps for refugees or internally displaced persons (IDPs). Events of the conflict itself also have an effect marking spaces with new narratives of massacres, resistance, heroism, or death.

Heritage sites frequently sustain economies at various scales. At the local level sellers of souvenirs and tour guides can come to rely heavily on tourists and pilgrims for income as do the providers of related services including accommodation, food 
provision, and transportation for their revenue. Nationally, cultural heritage driven tourism has become such a central element of economies around the world that its destruction can have a similar effect to removing a key industrial sector: annual tourist income in Croatia for instance, which today accounts for nearly $20 \%$ of the country's GDP, was severely affected by war and its aftermath (Orsini and Ostojić 2018). These are the direct economic impacts of cultural destruction; indirectly it also results in a loss of investment in a region and in the depletion of local capacity, as anyone with the means flees the conflict, often staying abroad even once this had ended. The combination of the financial neglect and population/skills loss, with the accompanying blight as places are abandoned, results in a far-reaching economic consequences.

The moral harm dimension of cultural property destruction was first addressed in the context of indigenous populations. The UNESCO Declaration of San José (1981) defines ethnocide as where: 'an ethnic group is denied the right to enjoy, develop and transmit its own culture and its own language, where collectively or individually. This involves an extreme form of massive violation of human rights and, in particular, the right to ethnic groups to respect for their cultural identity...' ${ }^{13}$ The moral harm represented by being denied these rights is further accentuated by the fear caused by being having ones cultural sites and practices singled out for destruction, living under constant threat that one's identity will cause one to be targeted, the exclusion from a reframed notion of who is included in the national group, and the constant portrayals of one's cultural identity as inferior and deviant from a redefined norm of acceptability. Subsequent human rights jurisprudence has increasingly tried to capture this harm and reflect it in its approach to reparations, which looks beyond the individual past harm to the present collective suffering and future existence.

The increasing criminalisation of the destruction of cultural property in international criminal law seeks to capture this more anthropocentric understanding of the harm, going beyond property to recognise harm to communities and people connected to it (Abtahi 2001). This includes war crimes of 'internationally directing attacks against buildings dedicated to religion, education, art, science or charitable purposes, historic monuments'; persecution of a group or individuals' cultural identity as a crime against humanity; and even the requirement of mental intent for genocide. ${ }^{14}$ While the intentions underlying the destruction of cultural heritage can be difficult to pin-down, criminalisation of the destruction of cultural property is 
intended to capture the criminal intent to wipe out the shared heritage and existence of minority groups, as seen with the attacks against the Yazidi by ISIS in Iraq, ${ }^{15}$ or desecration and destruction of Cham mosques in Cambodia during the Khmer Rouge regime (Killean et al 2018). As such, such physical destruction of the cultural manifestations of the group can rupture the social connections and trust between individuals, families and communities within such a group and with the rest of society, who can feel intimidated from practicing their culture and increasing socially marginalised and isolated.

Further impacts occur when communities are prohibited from practicing their religions, speaking their languages, or transmitting their stories and values to younger generations. Such loss is further exacerbated when the religious and cultural leaders of communities are targeted. For when the conveyors of a community's history and values are killed this truncates their transmission into the future and creates ruptures that are difficult to overcome subsequently. ${ }^{16}$ These can be viewed as collective and inter-generational harms to a community, since tangible and intangible heritage are the principal means by which older generations pass down and communicate collective memory and shared identity to present and future generations. They can also cause spiritual harm. In the case of $A l$ Mahdi involving the destruction of the World Heritage site by Islamist militants, the targeting of the ancient mausoleums that the community believed spiritually protected Timbuktu from bad fortune, 'shattered the community's collective faith that they were protected. ${ }^{17}$ The attack by Ansar Dine not only caused them to lose their ability to worship the saints and their ancestors, but it also caused psychological and moral harm to the community in terms of their spiritual world view. Some of the victims who applied for reparations at the ICC spoke of their 'shock' and 'bereavement' at the destruction, which affected their emotional and spiritual well-being. ${ }^{18}$ This destruction of such nationally and internationally valued cultural property rippled out into Mali and the international community. The Malian Minister of Culture held that the attack on the World Heritage sites at Timbuktu as "an attack on what fuels our soul, on the very essence of our cultural values. Their objective was to destroy our past, our culture, our identity, and in fact our dignity." ${ }^{19}$ Given the scale of harm caused by the destruction of cultural property, reparations can only deliver so much in remedying the past. Therefore to maximise resources, appropriate forms of redress must be made, and we turn to this in the next section. 


\section{Making appropriate reparations for the destruction of cultural property and}

\section{heritage}

Reparations cannot undo all the harm that has been caused, but it can serve to publicly acknowledge and alleviate some of the ongoing suffering of victims and affected communities. As such, reparations are in themselves expressions of moral messages of values in transitional societies from conflict or authoritarianism. Nevertheless, contemporary practice and human rights law strongly suggests that compensation or restitution is not enough, but reparations need to be appropriate to the harm caused, which necessarily requires victims to be involved in the design, process and implementation of such measures to ensure correctly align to their needs. In this section we outline some of the tensions around implementing appropriate reparations for destruction of cultural heritage including who is considered eligible as a victim, what forms reparations should take and who is responsible for carrying them out. The final section reflects on the reality of repairing cultural heritage after conflict.

\section{Determining who is victimised}

As we have seen, the harm caused by the destruction of cultural property can be extensive, reaching across borders, peoples and generations, with, as the Hague Convention makes clear, potentially universal interest and impact. This raises difficult questions as to who can claim reparations for the destruction of cultural heritage. The law in this area usually focuses on maximising redress to those most proximately affected, a proposition which at least in part acknowledges the impossibility of addressing al facets of the loss. ${ }^{20}$ In the $A l$ Mahdi case, the ICC recognised that, as Timbuktu was a World Heritage Site, Mali and the international community, represented by UNESCO, had suffered harm, but it addressed the proximity point by awarding them only a symbolic $€ 1$ each. ${ }^{21}$ The Court distinguished the inhabitants of Timbuktu as suffering 'disproportionately more harm' as a result of the attacks on the mausoleums. ${ }^{22}$ By concentrating reparations on the local community, who are responsible for maintaining the cultural heritage, the Court believed it would maximise the effect of reparations by strengthening their ability to preserve the site. ${ }^{23}$

There are also individual and collective dimensions to harm in prioritising who can claim reparations. The ICC in the Al Mahdi case held that those whose ancestors' burial sites had been damaged suffered a more direct and intense form of 
moral suffering than the rest of the community in Timbuktu, therefore the Court prioritised compensation to these individuals, with collective memorial measures for the rest of the community (Drumbl 2019, 86). ${ }^{24}$ There also has been recognition that collective groupings or associations can claim reparations as victims, in addition to individuals. In a number of cases involving violation of the rights of Islamic and Roman Catholic individuals in Bosnia and Herzegovina and Republic Srpska, these communities have been recognised as having legal standing as victims as legal persons. This is due to them qualifying for allegations of violations against their members as well as legal entities owning property that has its property rights infringed. ${ }^{25}$ This focus on individuals and communities most affected by the destruction of cultural property assists in making reparations more potent in their remedial value, but risks excluding the acknowledgement and redress of the harm suffered by those more indirectly affected.

\section{Appropriate forms of reparations}

Reparations are internationally recognised as encompassing five main forms to remedy serious violations of human rights and grave breaches of international humanitarian law: restitution; compensation; rehabilitation; measures of satisfaction; and guarantees of non-repetition. ${ }^{26}$ Restitution includes restoration of property or rights. Compensation involves both pecuniary (quantifiable) and non-pecuniary (moral) awards to cover the cost and moral harm suffered by victims, whether through a lump sum or a pension. Rehabilitation entails physical and mental care, as well as social and legal services to heal a victim's personal integrity and social functioning. Measures of satisfaction are public acknowledgements of victims' harm and symbolic redress to reaffirm their dignity, such as memorials, apologies, recovery of those disappeared, and investigations. Guarantees of non-repetition are public commitments and reforms by the state to prevent violations recurring in the future, such as human rights training of the armed forces and civilian oversight (Moffett 2017). These measures are intended to be awarded together so as to complement their various strengths and weaknesses, as well as to assist in remedying the personal and moral nature of the harm caused.

Given the property perspective on cultural objects and buildings, restitution has traditionally been viewed as a way to remedy wrongful appropriations. As part of the Treaty of Versailles (1919), the German government was ordered to return 
property it had confiscated in Belgium and France. ${ }^{27}$ Under the Treaty of Sevres (1920), provisions of restitution of homes and businesses of those forcibly displaced for fear of massacre, also provided that where victims had died without heirs, their property would be transferred to the community, not the state. ${ }^{28}$ Following this practice a restitution system was created to provide property (or compensation in lieu of property) to Jewish victims of the Holocaust in respect of property looted by the Nazis (see Taylor et al 2009). Restitution can also cover restoring land sites/titles to communities where new buildings have been built over destroyed cultural property, such as the case of Banja Luka where a new businesses had been built on the site of a destroyed mosque. ${ }^{29}$ Restitution-in-kind can also be ordered to victims, where it is impossible to transfer the land or property back to them, such as where new cultural property belonging to another community now occupies the site. ${ }^{30}$

Rehabilitation of cultural property includes restoration of damaged and destroyed buildings, but it can also include measures to preserve and develop the cultural heritage of a group or people (Vrdoljak 2011, 18). The 1964 Venice Charter set out specific guidelines for the restoration of cultural property such that its authenticity and integrity might be preserved. Ideas about the aim and object of restoration however, have since evolved. The 1979 Australia ICOMOS Charter for the Conservation of Places of Cultural Significance (known as the Burra Charter) introduced the notion of cultural significance as a measure of authenticity, to guide preservation, restoration and reconstruction in a way that looked beyond physical integrity to include the meaning of heritage for communities. The 1994 "Nara Document on Authenticity" updated the Venice Charter recognising that respecting cultural and heritage diversity required acknowledging that judgments about authenticity could be linked to a variety of sources of information and valuation that were not entirely dependant on material continuity but included essential intangible elements (Nara Document 1994, Arts. 5-13). More recently, the 2018 Warsaw guidelines of the World Heritage Committee have attempted to marry the needs of reconstructing cultural heritage sites destroyed by war while at the same time as protecting Outstanding Universal Value such that conditions of authenticity and integrity are not compromised. ${ }^{31}$ Importantly, amongst the set of principles set out in Warsaw are ones that highlight the importance of consulting with and obtaining the informed consent of affected communities, allowing time for reflection rather than knee-jerk reactions, and the delicate balance to be sought between memorialisation 
and reconciliation. Tensions in the objectives remain, not least between ambitions to 'build back better', protect Outstanding Universal Value, and return to war-affected communities that which they have lost (World Heritage Committee 2018, 3-4) but the integration of nuance and acknowledgment of the possible contradictions is paramount.

Courts have been more inclined to focus rehabilitation on the human impact of cultural destruction on communities and groups. ${ }^{32}$ This can require the "necessary material, medical, psychological and social assistance' to victims and affected communities to restore their 'functional ability' (United Nations 1985, Principle 14; Sandoval 2009, 8). Such harm has implications for subsequent and future generations within a group or community. In our own research on the Cham in Cambodia, a number of focus groups suggested that education would be an effective way of rehabilitating the intergenerational harm caused to the group's cultural knowledge and traditions (Killean et al 2018). Other courts and transitional justice bodies have ordered or recommended that violations and the cultural history and practices of minority groups and indigenous peoples be integrated into national curriculums to preserve such groups' heritage, promote reconciliation and to prevent their recurrence. ${ }^{33}$

Some victims or injured parties may prefer compensation instead of restitution for the damage caused to cultural property and heritage. ${ }^{34}$ Compensation has been awarded for the reconstruction of historic monuments and religious buildings destroyed during conflict. For instance the Eritrea-Ethiopia Claims Commission ordered \$50,000 in compensation against Ethiopia for blowing up the 2,500 year old Stela of Matara obelisk in Eritrea, ${ }^{35}$ and awarded \$4,500,000 to Ethiopia for the looting and shelling by Eritrean forces of 164 Ethiopian churches, mosques and associated buildings. ${ }^{36}$ Compensation can also be used to fund memorials or funeral arrangements in the appropriate cultural and religious way of a group for those who are killed. ${ }^{37}$ Compensation can be used to reimburse wide range of loss and harms, such as moral harm caused by damage to holy or religious sites and a group's cultural identity ${ }^{38}$ discrimination for cultural destruction, ${ }^{39}$ and economic loss. ${ }^{40}$

Compensation for economic loss caused by damage to cultural property is somewhat more debateable, given the difficulty of measuring such loss. Generally international administrative claims commissions have rejected impacts on tourism as a basis for compensation, for being speculative and lacking sufficient evidence 
(Matheson 2012, 235). ${ }^{41}$ There is some recognition that compensation or financial development programmes may be appropriate for economic loss caused to communities, where their livelihood such as indigenous people and eco-tourism. ${ }^{42}$ In the case of Al Mahdi at the ICC, the Court ruled that compensation would only be paid to those whose 'livelihoods exclusively depended' on the mausoleums at Timbuktu. ${ }^{43}$ These included the guardians of the mausoleums, maçons responsible for maintaining them and businesses that would not exist without them, such as those which sold holy sand. ${ }^{44}$ For the wider community in Timbuktu the ICC ordered collective measures to be implemented to alleviate their economic loss, which included community-based educational and awareness raising programmes, return/resettlement programmes, and a 'microcredit system' that would assist the population to generate income. ${ }^{45}$ Trust funds have been established to assist community development in redressing the wider consequences of cultural destruction. ${ }^{46}$ This reflects that compensation alone cannot adequately alleviate the scale and communal nature of suffering caused by the destruction of cultural property.

Courts have also ordered measures of satisfaction (for example apologies, memorials, and search for those disappeared) as means to acknowledge publicly and repair the moral harm suffered by victims and communities. Such measures are intended to 'awaken ... public awareness to avoid repetition', and 'maintain remembrance of the victim', ${ }^{47}$ addressing those losses of 'honour, dignity and prestige' caused by a violation or crime that cannot be redressed by restitution or compensation, due to their intangible and unquantifiable nature. ${ }^{48}$ The patterns of such redress are nuanced and complex. Memorials, for example, can operate as physical reminders in public spaces, confronting society to recognise the moral harm caused to a group by the destruction of its culture. However, memorials are not a universal panacea and can also become sites of contestation by celebrating the instigators or leaders of armed conflict, marking the victims as martyrs of one part of the conflict while neglecting others. This selective and political memorialisation can impact future cohesion by signalling one group as having differently suffered from others or being more worthy of being remembered. Recent violence around Confederate monuments in Charlottesville and the protest movement against monumental commemorations of Cecile Rhodes provide contemporary examples of just how contentious memorials can come to be, particularly when they serve in part to silence victims of past violence (Maurantonio 2018). 
Memorials manifested in stone are also a Western tradition not globally shared: more recent forms of memorials in Rwanda, for instance, or community peace museums in Kenya, illustrate that there can be more locally meaningful memorial gestures (Walters et al 2017). There is also a question about whether new memorials should be built or old ones modified/left damaged to evidence disturbance and rupture. One answer to this has been to add layers of interpretation to existing memorials, contextualising and updating them. Regardless of their intention behind the initial memorial gesture these inevitably change as the witnesses of events disappear, new voices are added to the interpretation of events, and collective memories themselves rewritten (White 2016).

The forms of reparations discussed thus far are remedial in nature, but there may also be a need for more proactive measures to prevent the recurrence of such crimes in the future. Guarantees of non-repetition are commitments made by states to prevent past violations from reoccurring through reforming state institutions and tackling structural victimisation (Mégret 2009, 130). In the aftermath of the destruction of cultural property, communities may be displaced and fearful of returning to their homes in case of reprisals or discrimination. Guarantees of nonrepetition may comprise human rights training for military and police forces, including sensitive treatment of minorities' cultural practices; education on diverse cultures; security to allow displaced persons to return home; and repeal of discriminatory laws and practices that inhibit minority groups' culture. For example the Treaty of Sevres, alongside providing restitution to victims of massacres and forced displacement, also required the Turkish government to remove perpetrators from the area involved. ${ }^{49}$ In Bosnia, in cases involving the Muslim graveyard in Prnjavor, courts have ordered the revocation of burial restrictions on grounds of discrimination and violation of the enjoyment of the right to freely practice religious beliefs. ${ }^{50}$ Such proactivity is particularly important in societies transitioning away from conflict, lest the narratives that drove such violence continue to dominate debates on reparations, where responsible actors try to obscure their responsibility and justify their actions through self-serving laws and politics.

\section{Who is responsible for repairing cultural property?}

If the destruction of cultural property during armed conflict can involve a range of actors pursuing different agendas and motivations, the reconstruction and 
commemoration landscape is no different. Varying actors are matched with varying aims: to recover what was lost or take the opportunity to build anew as though on a blank slate (Sørensen \& Viejo Rose 2015). Reconstruction has manifold aspects, each with often complementary, but distinct agendas: re-visioning the post-war nation and its future; rewriting history to present the past in light of the conflict; remembering by re-inscribing the collective memorial narrative with new sites; re-codifying the politics of space with new value frameworks; and repairing the damage caused (Viejo Rose 2011,199).

International law recognises individual and state responsibility for reparations, but it can take years to seek justice at national or international courts, or to find political agreement. In the meantime, affected communities find ways to rebuild. In Cambodia, after the Khmer Rouge destroyed dozens of mosques, the Cham community began to fundraise abroad to fund the reconstruction of their mosques, or the building of new ones (Killean et al 2018). ICCROM has also been running capacity building programmes in post-conflict countries so that communities can be trained, and just as importantly employed, to restore their own heritage sites.

Reconstruction can be a collaborative effort between donors, civil society, local community and national reparations programmes or international legal forums. This can be seen in the aftermath of the Plan de Sanchez massacre in Guatemala, where survivors raised funds with the Catholic Church and NGOs to build a church to memorialise those killed, who were buried underneath it (Sanford 2003, 245). When the case reached the Inter-American Court of Human Rights, alongside other reparations, it awarded $\$ 25,000$ to the victim community for the chapel to support collective memory of the massacre by raising public awareness to avoid its recurrence and to 'keep alive the memory of those who died. ${ }^{51}$

It is important to remember that reparations as a right serves as a measure of accountability. This distinguishes them from assistance, development or community rebuilding efforts, in that they acknowledge the wrongfulness of the violation committed against individuals or communities, and oblige those responsible to recognise such harm and make efforts to remedy the ongoing suffering. In the $A l$ Mahdi case, where UNESCO had reconstructed most of the Timbuktu mausoleums, the ICC nonetheless found Mr Al Mahdi personally liable for $€ 2.7$ million. The Court did not take into consideration the efforts made by UNESCO as to do otherwise would 'understate the amount of harm actually caused' and 'depriv[e] victims of their 
right to a remedy' ${ }^{52}$ Perhaps a plausible intersection of reparations, assistance and development is that responsible actors could indemnify the cost of such reconstruction (supported by donors if need be), and make public acknowledgements of responsibility and renunciation of such violence, and if appropriate an apology.

\section{The reality of repairing the destruction of cultural property after conflict}

Rebuilding what has been damaged or destroyed during conflict can be as politically motivated as the destruction that caused it (Bevan 2016, 176). The reconstruction of cultural property can reflect the new power relations and tensions over whose cultural property is worth being rebuilt, whose suffering remembered, and even whom obtains the lucrative contracts to reconstruct (Bevan 2016). Such reconstruction can also reflect the international community's agenda or priorities, as with Mostar Bridge where the aim was not only to recover the heritage site, but also to symbolise and even to act as a motor of reconciliation (Viejo Rose 2013,133). That the reconstruction project failed in this second reparative goal is an important lesson here. The reasons for the failure are multiple and have been discussed elsewhere (Viejo Rose 2013; and Mezev 2007), but they can be synthesised as: an indifference to fully appreciate the symbolic and intangible heritage of the site and its place within the broader historic and socio-political heritage landscape of Mostar; a disregard to fully listen to the messages being sent locally on the decisions made in the reconstruction, including who was consulted and what company won the contract; and the insistence on a project time-frame that disregarded slower more inclusive approaches.

The literature on reparations in transitional justice and on heritage reconstruction in the aftermath of conflict both identifies the challenge of how the restoration should look (Verdeja 2006; Viejo Rose 2013,126). There are questions about how far legal, political and architecture efforts should reconstitute what has been lost, and whether restoration to the pre-conflict situation adequately redresses the harm caused. Indeed the focus of international law on preservation of past practices and cultural property may encourage such culture remaining static (Mezey 2007, 2005). At the same time such physical reconstruction of cultural property can also create a 'parallel process of re-imagining the country's past, recodifying its value system and formulating the resulting narratives'(Viejo Rose 2013,127).

There is a danger that the cultural identity and heritage of a targeted group are shackled to their past destruction (Novic 2016, 196). This risks creating a simplified 
understanding of the harm, and 'fixes' a static notion of a group's or people's culture, which in itself is 'unfixed, dynamic, and unstable' (Mezev 2007, 2005). Memorials created to honour those killed in a group or community may become the focus of their cultural existence. Such reconstruction can also create a hierarchy of victimhood in designating which cultural property and heritage is to be reconstructed and preserved after a conflict, and is worth future generations to know and to remember. In turn such priorities exclude, silence and neglect other groups that do not fit the wider political narrative of the transition or those in power. This can be seen in the selective remembrance of the Spanish Civil War in Spain, where memorials only commemorated the Nationalists who had died in an attempt to obliterate the public remembrance of those Republican soldiers killed (Viejo Rose 2103, 135).

Alternatively, new influences can change the direction of the practice of heritage and the design of cultural property, according to the background of donors including the possible preference of liberalised peacebuilding to eschew, for example, the reconstruction of religious buildings from reasons of multi-culturalism or neutrality (Viejo Rose 2013 \& Barakat 2007); or the cultural fusion effected by the return of displaced persons. This can reflect a natural evolution of a group or people's culture, which in itself grows through 'appropriations, hybridizations, and contaminations' (Mezey 2007, 2006). There remains a risk that selective reconstruction accentuates the very divisions that it seeks to dilute, creating community division and reinforcing the motivations for destruction. We find a possible example in Sarajevo for instance, where the international community funded the reconstruction of what was deemed to be the most representative building of each of three religious communities.

Post-war contexts are marked by changed and often significantly imbalanced power relations between affected communities and foreign actors, including donors. Such changes represent opportunities for foreign donors, 'cultural entrepreneurs', or international organisations, and this may impact the heritage landscape. For example in the Balkans, the rebuilding of traditionally Ottoman designed mosques in more Wahhabi architecture, reflected the support of the Saudi government (Novic 2018, 218-219; Viejo Rose 2007,112). While the involvement of the international community in the form of parachuting 'experts' in and out of situations and 'sugar coating' peacebuilding has proven to be ineffective, if not directly detrimental, the participation of the communities affected by cultural property destruction in the 
reconstruction process can be an important part of building their resilience and reconstituting essential elements of identity, agency, and dignity. This participation goes further than consultation and may include their input on design, process, and the articulation of their interests (Barakat 2007, 33).

A further challenge is ensuring security in an area to allow those displaced or targeted to return to their homes. This is a particular problem in cases involving the intentional destruction of cultural heritage, where groups are singled out to be ethnically cleansed from an area. Such cases will require guarantees of non-repetition to protect minority groups and communities, as well as facilitate their return and reintegration where they have been displaced..$^{53}$ In the Al Mahdi case, the ICC Trust Fund for Victims faces ongoing violence as it seeks to implement the reparations award, which creates difficulties on providing more public acknowledgment measures to avoid victims or the community being targeted. In the week of the reparation judgment, armed militants killed seven security guards at the UN peacekeeping base. $^{54}$

There is also a sense of victim competition deprioritising reparations to groups who suffered destruction or damage to their cultural heritage, with priority given to programmes addressing physical harm. In such circumstances, a community or group may come together to reconstruct their cultural property, perhaps seeking donor assistance; but the danger with this approach is that it neglects redressing the justifications that fuelled such destruction, and compelling those who caused the harm to face the consequences. While reparations are not a panacea, they can provide legal and political leverage to groups who have suffered from cultural destruction to seek redress for their harm. International norms on reparation need to be nuanced by the local context and the interests of the victims most affected by the destruction of cultural property. In itself international law provides a limited ambit for reparations for cultural property and heritage destruction, but the increasing jurisprudence and state practice in transitional societies is increasingly recognising the importance of remedying the material, moral and cultural harm suffered by individuals, groups and communities (Dijkstal 2019). This does not mean cultural relativism should allow the dilution of states and other actors' obligations to make reparations or ensure victims' rights; ${ }^{55}$ but it does suggest the need for processes and practices of reflexivity between international law and the lived experience of victims. 


\section{Conclusion}

The targeting of cultural property and the cultural practices of groups and communities causes serious damage to their well-being, dignity and continuity of identity and heritage. While international organisations dedicated to heritage have been active in developing preventive measures for such destruction, creating risk preparedness plans, and leading some reconstruction efforts, the idea of reparations as remedial measures that the Al Mahdi case introduced are still relatively underexplored. This article has sought to move beyond the focus of international law on the three Ps' approach (protect, preserve and prosecute) to encourage a broader discussion on the place of reparations (PPPR).

There is some nascent state practice and international jurisprudence on reparations for destruction and damage of cultural property, but there needs to be a broader vision of what this would look like in practice. In this article we have tried to set out what reparations for cultural heritage destruction could look like. We recognise that there are challenges in the reconstruction of cultural heritage after conflict, where the politics that drove the violence have not simply evaporated. Nevertheless, taking a reparations approach to this issue goes to the heart of the broader three Ps' approach in ensuring that culture developed by individuals, groups, communities and people should be cherished and maintained as a means to speak across time to future generations on the nature of humankind. This may require it to be stipulated in any future resolutions, conventions or treaties on cultural heritage. Reparations can help support communities and individuals to remedy past violations, but also should not be technocratically top-down reproductions without the informed consent and participation of victims. A reparation approach to cultural property restoration requires a participatory approach to cultural heritage protection. This inclusive and participatory approach through reparations evinces the shared ownership of such culture in its reproduction and sustainability for posterity.

\section{Notes:}

1. Such as the German army's sack of the Belgium city of Leuven in WWI.

2. For instance, looting by Soviets of German cultural property as 'reparations' for items the Nazis looted earlier in the war in Eastern Europe. See Gattini (1996).

3. Prosecutor v. Jokić, IT-01-42/1-S, Sentencing Judgment, 18 March 2004, para.52. 
4. Convention (II) with Respect to the Laws and Customs of War on Land and its annex: Regulations concerning the Laws and Customs of War on Land. The Hague, 29 July 1899; and Instructions for the Government of Armies of the United States in the Field (Lieber Code), 24 April 1863, Articles 34-36.

5. Articles 3 and 56, Convention (IV) respecting the Laws and Customs of War on Land and its annex: Regulations concerning the Laws and Customs of War on Land, The Hague, 18 October 1907.

6. Draft convention on the crime of genocide, Economic and Social Council, 26 June 1947, E/447, p49.

7. Preamble, para.3. Article 28 also provides general prosecution provisions for state parties to implement in their national criminal frameworks. The 2003 Convention for the Safeguarding of the Intangible Cultural Heritage focuses more on protection and preservation of intangible heritage.

8. Article 3 prohibits the use of cultural property as war reparations under the First Protocol to the Convention for the Protection of Cultural Property in the Event of Armed conflict 1954.

9. Factory at Chorzow, PCIJ Decision on Jurisdiction Judgment No. 8 of 26 July 1927, p21. See also Article 31, Articles of State Responsibility, ILC.

10. For instance ICOMOS's "Post-Trauma Reconstruction Colloquium" (Paris, 4 March 2016) and COE's report "Cultural heritage in crisis and post-crisis situations" (Doc. 13758, 18 April 2015).

11. Blake v Guatemala, Reparations, Series C No. 48 (IACtHR, 22 January 1999), para. 31; and Papamichalopoulos and Others v Greece, para. 34.

12. Germany v Poland, The Factory at Chorzow (Claim for Indemnity) (The Merits), Permanent Court of International Justice, File E. c. XIII, Docket XIV:I Judgment No. 13, 13 September 1928, para.125.

13. UN Doc.E/CN.4/Sub.2/1982/2/Add.1, Annex VI and Vrdoljak 2008.

14. Article 8(2)(b)(ix) and Article 8(2)(e)(iv); Blaškić, Trial Judgement, IT-95-14-T, 3 March 2000, para.227, and Karadžić, IT-95-5/18-T, 24 March 2016, para.531; and Krstić, IT-98-33-T 2 August 2001, para.580. See Gerstenblith (2016).

15. http://www.npr.org/sections/parallels/2015/02/13/385802886/outmanned-andoutgunned-fighters-defend-yazidi-shrine-against-isis.

16. They provide 'disruptions of culture': Al Mahdi para.85.

17. Al Mahdi para.85-86. 
18. Submissions of the Legal Representative of Victims on the principles and forms of the right to reparation, ICC-01/12-01/15-190, 2 January 2017, para.76-77.

19. Malian Ministry of Culture, «Projet de discours de Monsieur le Ministre de la Culture à l'occasion de l'ouverture de la journée de solidarité pour le Mali », MLIOTP-0004-0292, p. 0294 (unofficial internal translation), cited by OTP in ICC-01/1201/15-139-Red, para.19.

20. Aloeboetoe and others v Suriname, Judgment of September 10, 1993 (Reparations and Costs), para.48.

21. Al Mahdi, para.106.

22. Al Mahdi para.52. No reparation applications were made on behalf of UNESCO, who viewed the local community as the primary victims.

23. Al Mahdi, para.55.

24. Al Mahdi, para.89-90.

25. The Islamic Community in Bosnia and Herzegovina v The Republika Srpska, Decision on the admissibility and merits, Human Rights Chamber of Bosnia and Herzegovina, Case No. CH/96/29, 11 June 1999, para.125-131.

26. 2005 UN Basic Principles.

27. Articles 245-247. Similar provisions on restitution were made for non-Turkish victims forcibly driven from the homes in the Treaty of Sevres, Article 144.

28. Article 144(3).

29. The Islamic Community, Case no. CH/96/29, pp.209-213; Islamic Community in Bosnia and Herzegovina (Mrkonjić Grad) v Republika Srpska, Case no. CH/01/7701, 22 December 2003, para.165-166.

30. See The Islamic Community in Bosnia and Herzegovina v. The Republika Srpska, Decision on admissibility and merits, Case no. CH/98/1062, 9 November 2000, para.117-123.

31. The "Warsaw Recommendation on Recovery and Reconstruction of Cultural Heritage" was developed in May 2018 at a conference held organised by the UNESCO World Heritage Committee.

32. Al Mahdi, para.83.

33. Plan de Sánchez massacre, para.110; Members of the village of Chichupac and neighbouring communities of the Municipality of Rabinal v. Guatemala, Preliminary Objections, Merits, Reparations and Costs. Judgment of November 30, 2016. Series C 
No. 328, para.319; and South African Truth and Reconciliation Commission Report Vol. 5, p175.

34. Croatia v Serbia, ICJ, Croatia memorial, Volume 1, 1 March 2001, para.8.81.

35. Final Award - Eritrea's Damages Claims, Eritrea-Ethiopia Claims Commission,

17 August 2009, para.221-223

36. Final Award - Ethiopia's Damages Claims, 17 August 2009, para.383-386.

37. Selimović and Others v. Republika Srpska, Decision on Admissibility and Merits, CH/01/8365 (HRC BiH), 7 March 2003, para.217.

38. Kichwa Indigenous People of Sarayaku v. Ecuador. Merits and reparations.

Judgment of June 27, 2012. Series C No. 245, para.323.

39. Islamic Community in Bosnia and Herzegovina (Mrkonjić Grad) v Republika Srpska, Case no. CH/01/7701, 22 December 2003, para.174.

40. Al Mahdi, Decision on the Updated Implementation Plan from the Trust Fund for Victims, ICC-01/12-01/15-324-Red, 4 March 2019, para.31.

41. Final Award Ethiopia's Damages Claims, Volume XXVI pp. 631-770, 17 August 2009, para.461; Compensation for Business Losses Resulting from Iraq's Unlawful Invasion and Occupation of Kuwait, United Nations Compensation Commission, UN Doc S/AC.26/1992/15, para.5.

42. Sarayaku, para.316-217.

43. Al Mahdi reparations order, para.81.

44. Al Mahdi ibid., para.73 and 81.

45. Al Mahdi, para.83.

46. Moiwana Community, para.214-215; and Sarayaku, para.317.

47. Principle 22, United Nations (2005); 19 Tradesmen v Colombia, paras 272-273; Myrna Mack-Chang v Peru, para. 286.

48. Case concerning the difference between New Zealand and France concerning the interpretation or application of two agreements, concluded 9 July 1986 between the two states and which related to the problems arising from the Rainbow Warrior affair, 30 April 1990, UNRIAA, vol. XX, 215-284, pp. 267-273; Corfu Channel case; see ILC Commentary on RSIWA (A/56/10), 2001, p. 105; Arrest Warrant of 11 April 2000 (Democratic Republic of the Congo v Belgium) [2002] ICJ Reports 3, para. 75. See also Article 37(2)-(3), Articles on State Responsibility. 49. Article 144(2). See Vrdoljak (2011), p21. 
50. The Islamic Community in Bosnia and Herzegovina v The Republika Srpska, Case no. CH/99/2177, 11 February 2000; also Dževad Mahmutović v The Republika Srpska, Case no. CH/98/892, 8 October 1999.

51. Plan de Sanchez, para.104.

52. Al Mahdi para.66 and 114.

53. Moiwana Community, para.212.

54. Deadly attack targets UN mission in Timbuktu, Mali, BBC News, 14 August 2017.

55. Al Mahdi, ICC-01/12-01/15-236, para.147.

\section{References:}

Abtahi, Hirad. 2001. The Protection of Cultural Property in Times of Armed Conflict: The Practice of the International Criminal Tribunal for the Former Yugoslavia, Harvard Human Rights Journal 14: 1-32.

Ascherson, Neal. 2006. Cultural destruction by war and its impact on group identities, in Cultural Heritage in Postwar Recovery: Papers from the ICCROM Forum held on October 4-6 2005, ICCROM, (2006) 17-25.

Balkan Reports. 2005. RFE/RL Investigates Saudi Financing of Islamic Revival in Bosnia, 26 March 2005. Available at: https://www.rferl.org/a/1340938.html Last viewed 14/06/2019

Barakat, Sultan. 2007. "Postwar reconstruction and the recovery of cultural heritage: critical lessons from the last fifteen years", in N Stanley-Price (ed) Cultural Heritage in Postwar Recovery, Rome: ICCROM.

Bevan. Robert. 2016. The Destruction of Memory: Architecture at War, Reaktion.

Blake, Janet (2017) 'Protection of intangible cultural heritage in the event of armed conflict: an imperative for cultural heritage, humanitarian and human rights law' Europa Ethnica, 74(3): 73-81.

Brosché, Johan, Mattias Legnér, Joakim Kreutz, and Akram Ijla, 2017. "Heritage under attack: motives for targeting cultural property during armed conflict", International Journal of Heritage Studies, 23(3) (2017), 248-260.

Cunliffe, Emma, Nibal Muhesen, and Marina Lostal, 2016. "The Destruction of Cultural Property in the Syrian Conflict: Legal Implications and Obligations", International Journal of Cultural Property 23: 1-31. 
Dijkstal, Haydee J. "Destruction of Cultural Heritage before the ICC The Influence of Human Rights on Reparations Proceedings for Victims and the Accused", Journal of International Criminal Justice 17(2) (2019), 391-412.

Drumbl, Mark A. "From Timbuktu to The Hague and Beyond: The War Crime of Intentionally Attacking Cultural Property", Journal of International Criminal Justice, 17(1)(2019), 77-99.

Gattini, Andrea. 1996. "Restitution by Russia of Works of Art Removed from German Territory at the End of the Second World War", European Journal of International Law 7: 67-88.

Gerstenblith, Patty. 2016. "The Destruction of Cultural Heritage: A Crime against Property or a Crime Against People?", The John Marshall Review of Intellectual Property Law 15: 336-393.

Harvey, David C. 2001. "Heritage Pasts and Heritage Presents: temporality, meaning and the scope of heritage studies", International Journal of Heritage Studies, 7:4, 319-338.

ICOMOS. 1994. "Nara Document on Authenticity". Available at: https://www.icomos.org/charters/nara-e.pdf (Last accessed 31/07/2019)

Killean, Rachel, Robin Hickey, Luke Moffett, Dacia Viejo Rose, Farina So, and V. Orn. 2018. Cham: Culture and History Story of Cambodia. Documentation Center of Cambodia.

Kirshenblatt-Gimblett, Barbara. 1995. "Theorizing Heritage”, Ecomusicology, Fall, 39(33): 367-380.

Lenzerini, Federico. 2008. Reparations for Indigenous People: International and Comparative Perspectives. Oxford: Oxford University Press.

Lijnzaad, Liesbeth. 2010. Sleeping Beauty, "The Untold Story of the (first) Protocol to the 1954 Hague Convention", in N. Van Woudenberg and L. Lijnzaad (eds.), Protecting Cultural Property in Armed Conflict: An Insight into the 1999 Second Protocol to the Hague Convention of 1954 for the Protection of Cultural Property in the Event of Armed Conflict, Brill: 147-156.

Matheson, Matthew. 2012. International Civil Tribunals and Armed Conflict. Brill.

Maurantonio, Nicole. 2018. "Tarred by History: Materiality, Memory, and Protest", de arte, 53(2-3): 51-69.

Mégret, Frédéric. 2009. “The International Criminal Court Statute and the Failure to Mention Symbolic Reparations", International Review of Victimology 6: 127-147. 
Mezey, Naomi. 2007. "The Paradoxes of Cultural Property”, Columbia Law Review 107 (2007): 2004-2046.

Moffett, L. (2017), “Transitional Justice and Reparations: Remedying the Past?” in C. Lawther, L. Moffett, and D. Jacobs (eds.), Research Handbook on Transitional Justice (2017), 377-400.

Novic, Elisa. 2016. The Concept of Cultural Genocide: An International Law Perspective. Oxford: OUP.

O'Keefe, Roger. 2006. The Protection of Cultural Property in Armed Conflict. Cambridge: CUP.

Orsini, Kristian and Ostojić, Vukašin (2018), Croatia's Tourism Industry: Beyond the Sun and Sea, European Commission.

Sandoval, Clara. 2009. Rehabilitation as a Form of Reparation under International Law, Redress

Sanford, Victoria. 2003. Buried Secrets: Truth and Human Rights in Guatemala. London: Palgrave Macmillan.

Shelton, Dinah (2005). Remedies in International Human Rights Law. 2nd ed. Oxford: Oxford University Press.

Singh, Kavita. 2014. Museums, Heritage, Culture: Into the Conflict Zone. Reinwardt Academy, Amsterdam University of the Arts.

Smith, Laurajane. 2006. The Uses of Heritage. London: Routledge

Sørensen, Marie Louise Stig and Dacia Viejo Rose. 2015. War and Cultural Heritage. Biographies of Place. Cambridge: Cambridge University Press.

Taylor, Gideon, Greg Schneider and Saul Kagan. 2009. "The Claims Conference and the Historic Jewish Efforts for Holocaust-Related Compensation and Restitution", in C. Ferstman, M. Goetz and A. Stephens (eds.), Reparations for Victims of Genocide, War Crimes and Crimes against Humanity. Brill: 103- 114.

United Nations 1985, Declaration of Basic Principles of Justice for Victims of Crime and Abuse of Power, A/RES/40/34.

United Nations 2005, Declarations on the Right to Remedy and Reparations for Gross Violations of Human Rights and Serious Breaches of International Humanitarian Law, A/RES/60/147.

United Nations 2007, Declaration on the Rights of Indigenous People, A/RES/61/295. UNESCO 1950, Report on the International Protection of Cultural Property by Penal Measures in the Event of Armed Conflict, 5C/PRG/6 Annex 1, 8 March 1950. 
UNESCO 1970 "Convention on the Means of Prohibiting and Preventing the Illicit Import, Export and Transfer of Ownership of Cultural Property”.

UNESCO 2015 "Post-Conflict Reconstruction in the Middle East Context and in the Old City of Aleppo in particular" (Paris, 18-19 June 2015).

UNESCO 2018 "International conference on reconstruction: The challenges of World Heritage recovery”, Warsaw, 6-8 May 2018.

UNIDROIT 1995, "Convention on Stolen and Illegally Exported Cultural Objects".

Verdeja, Ernesto. 2006. A Normative Theory of Reparations in Transitional Democracies, Metaphilosophy Vol. 37, Nos. 3-4, July: 449-469

Viejo Rose, Dacia. 2007. "Conflict and the Deliberate Destruction of Cultural Heritage" in Y.R. Isar and H. Anheier (eds), Cultures and Globalization Series, vol.1, Conflicts and Tensions. London: Sage, pp. 102-116.

Viejo Rose, Dacia. 2011. Reconstructing Spain. Cultural Heritage and Memory after Civil War. Brighton: Sussex University Press.

Viejo-Rose, Dacia. 2013. "Reconstructing Heritage in the Aftermath of Civil War: Re-Visioning the Nation and the Implications of International Involvement", Journal of Intervention and Statebuilding, 7(2): 125-148.

Vrdoljak. Ana Filipa. 2008. "Reparations for Cultural Loss", in F. Lenzerini (ed). Reparations for Indigenous Peoples: International and Comparative Perspectives. Oxford: OUP, 197-228.

Vrdoljak, Ana Filipa. 2011. Genocide and Restitution: Ensuring Each Group's Contribution to Humanity, European Journal of International Law 22(1): 17-47.

Walters, Diana, Daniel Laven, and Peter Davis (eds). 2017. Heritage and Peacebuilding. Newcastle and Woodbridge, Suffolk: International Centre for Cultural \& Heritage Studies, University of Newcastle \& The Boydell Press. White, Geoffrey. 2016. Memorializing Pearl Harbour: Unfinished Histories and the Work of Remembrance. Duke University Press.

Woodhead, Charlotte. 2014. "Redressing historic wrongs, returning objects to their rightful owners or laundering tainted objects? 21st-Century UK remedies for Naziera injustices", International Journal of Cultural Property 21(2): 113-142.

World Heritage Committee. 2018. Warsaw "Recommendation on Recovery and Reconstruction of Cultural Heritage". Available at: https://whc.unesco.org/en/news/1826 (Last accessed 31/07/2019) 


\section{Endnotes}

